\title{
Multiple roles of student and instructor in university teaching and learning processes
}

\author{
Malcolm Brady \\ DCU Business School, \\ Dublin City University, \\ Dublin 9, Ireland. \\ Email: malcolm.brady@dcu.ie \\ Tel. +35317005188
}

\begin{abstract}
This paper examines six key university teaching and learning processes using Checkland's CATWOE mnemonic and the SIPOC model from lean operations theory. The analysis shows that students play a number of different roles in these processes: as customer, actor, supplier, raw material and end product. The analysis also shows that instructors play a number of different roles in these self-same processes: as supplier, actor and customer. The paper concludes that viewing students as customers is overly simplistic. The paper suggests that students, instructors and support staff must accept that students play a multiplicity of roles, sometimes simultaneously, in university teaching and learning processes. The paper suggests that awareness among instructors of the different processes taking place and of the roles that students and instructors themselves play in those processes will improve the ability of universities to carry out their teaching and learning mission.
\end{abstract}

Keywords: university, teaching, learning, process, student, customer

Acknowledgement: the author is grateful to the editor for his encouragement and to the two anonymous reviewers for their many and useful comments on the manuscript. 


\section{Multiple roles of student and instructor in university teaching and learning processes}

This paper carries out a detailed analysis of university teaching and learning processes and explores the various roles that students play in these processes, including the role of customer. Six key university teaching and learning processes are proposed and analyzed under the input-process-output systems paradigm. The paper follows a line of research that takes a process or systems view of the work of educational institutions (Weller, 1998; Walker and \& Ainsworth, 2001; Sasse et al., 2008; Stepanovich, 2009; Porter \& Córdoba, 2009; Flannery \& Pragman, 2010). The paper uses two specific systems analysis tools: the CATWOE mnemonic from soft systems theory (Checkland, 1985a) and the SIPOC model from the quality and lean operations literature (Pyzdek, 2003).

The paper follows a small number of broad assumptions about learning in general and universities in particular. It takes as its starting point that the primary mission of most universities is to carry out research into phenomena of interest and to disseminate the knowledge gained from this research by various means, primarily through teaching and publication. The first assumption therefore is that universities exist in order to codify knowledge and transmit it from one generation to the next in order that society moves forward (or at least does not lose knowledge). Secondly, it is assumed that universities transmit knowledge largely by means of prescribed, designed, formal degree programs comprising specified courses rather than through individual research, on the job training, apprenticeship, self-teaching, or ad-hoc learning (however note that higher-level learning is typically carried out through individual or team-based research). Thirdly it is assumed that a series of meetings, over some specified time period, takes place between instructor and student in order to engage student learning during a course. Fourthly, it is assumed that not 
all knowledge transfer can take place in class meetings and students must therefore invest additional time in study. Fifthly, it is assumed that student work is assessed and graded in order to verify the extent of student learning. These broad assumptions provide the underpinning for the teaching and learning processes analysed in this paper.

The paper makes two main contributions: firstly, it identifies and separates out several key teaching and learning processes and examines in detail the transformation that takes place during the process. The paper then identifies the various roles that students and instructors take on during each process; the identification of these roles and their implications for teaching and learning provides the second contribution of the paper.

The paper is laid out as follows. Section one briefly reviews the literature on learning paradigms and metaphors for students. In section two the analysis approach is presented and the process analysis techniques are introduced. Section three examines in detail six key university teaching and learning transformation processes. Section four presents a discussion of the implications of the process analysis for faculty and students.

\section{STUDENT METAPHORS AND LEARNING PARADIGMS}

This paper was prompted by a debate on the topic of 'student as customer' that took place a number of years ago in the university in which the author works. Unsurprisingly the debate became heated with strong arguments being made for and against. A similar debate is taking place in the academic literature with many authors recommending that academics view their students as customers and be responsive to their needs (Wallace, 1999; Bridges, 1999; McCollough \& Gremler, 1999; Obermiller \& Atwood, 2011). While the student-as-customer view has usefully placed emphasis on the student, a number of drawbacks to this view have also been presented, for example: class meetings may become popularity contests, education 
may become entertainment, grades may become inflated (Franz, 1998; Bailey, 2000; Ferris, 2002; Gross \& Hogler 2005; Acevedo, 2011). These concerns have resulted in a number of alternative metaphors for students being put forward. Franz (1998) views students as fitness trainees, to be directed and motivated by an instructor. Bailey (2000) and Armstrong (2003) view students as clients with whom academics should maintain a professional relationship. Ferris (2002 and 2003) and Gillespie \& Parry (2009) suggest a junior-partner or employee metaphor. Mintzberg \& Gosling (2011) view students as participants in the educational process. In contrast to the above papers where students are typically allocated a single role, this paper suggests that students take on a multiplicity of roles in teaching and learning processes, often simultaneously. The paper also suggests that instructors likewise play a multiplicity of roles. It is this multiplicity and simultaneity of roles played by the two primary actors that makes teaching and learning processes particularly complex.

The debate on the role of student in the learning process dovetails with discussion in the literature on the nature of teaching and learning itself. Approaches to teaching and learning in management education are in transition (Gallos, 2008) and in need of reform (Pffefer \& Fong, 2002). The traditional teacher-centric view of teaching and learning sees the instructor as the fount of knowledge, disseminating that knowledge through formal lectures. This view is gradually being replaced by a more student-centric approach to teaching and learning (Mintzberg \& Gosling, 2011; Berggren \& Söderlund, 2011) where students are actively encouraged by instructors to become more involved in class meetings, for example by discussing case studies, making presentations based on their own analysis, engaging in active commentary and criticism, reflecting on their own practice or completing learning journals. At the limit students co-create their own knowledge leading to a new learning paradigm where knowledge claims are viewed as social constructions (Bedeain, 2004) and that business 
education itself is a social construction (Antunes \& Thomas, 2007). Although there exist a number of different learning paradigms the series of teaching and learning processes put forward in this paper exist independently of the learning paradigm. For example, class meetings will take place whether they are teacher or student centric and whether knowledge is transferred or co-produced. The learning paradigm will of course have a major impact on how the class meeting process is carried out in practice.

\section{PROCESS ANALYSIS}

Viewing the work of an organization as a series of processes has become a paradigm in the business discipline since Michael Porter first put forward his concept of the value chain (Porter, 1985:ch.2). Other authors from the management literature have built on this theme: Michael Hammer (1990) suggested the need to examine and reengineer the large-scale business processes inherent in organizations. The quality and lean literatures have long taken the view that all work is a process (Crosby, 1979; Imai, 1986; Womack et al, 1991). In the field of economics Nelson \& Winter (1982) identified routines as the fundamental unit of business organizations and the basis for their evolutionary theory of the firm. An activity based approach is also evident in the marketing discipline where the 'service blueprint' concept demonstrated the usefulness of visualizing a service as a process (Shostack, 1982). This paper draws on this substantial literature of process-based thinking in its analysis of teaching and learning processes.

Inherent in the process view is the customer as receiver of the output of the transformation: that is, the 'next operation as customer' (Bhote, 1992). However, the concept of customer is neither simple nor straight-forward (Brysland \& Curry, 2001:392), and particularly so in a university context. Customers may be internal or external to the organization; customers may be multiple when a process results in several different outputs, each going to a different 
customer; there may also be confusion between those who receive a service and those who pay for it with either or both or none being referred to as customer. Checkland (1985a) defines the customer as the receiver of the output of the process. He recognizes that this 'customer' is not necessarily the one who pays for the service, and may not even want or require it. He adds that it may be useful to view the customer as the victim or beneficiary of the service and gives the example of a prisoner as victim (or beneficiary) of the prison service: he receives the service but does not pay for it and probably does not desire it. This paper adopts Checkland's view of the customer as beneficiary of the output of a process.

This paper focuses on the teaching element of the mission and uses the soft systems approach pioneered by Checkland (1985a and 1985b) and the SIPOC approach which derives from the lean operations literature (Pyzdek, 2003:388) to analyze these teaching related processes. The central tenet of the soft systems approach is that a process carries out transformational work on some input and produces some output: the output is a transformed version of the input. A starting point for this type of analysis is to focus on the transformation and to determine exactly what is being transformed. Checkland developed the CATWOE mnemonic to describe the six major elements in the transformation process: the customer $(\mathrm{C})$ who receives the output of the process and who is viewed as the victim or beneficiary of the process; the actors (A) who carry out the transformation; the transformation (T) itself where inputs are turned into outputs; the world-view (Weltangshauung) which represents the paradigm under which the transformation takes place; the owner $(\mathrm{O})$ of the process, who is also the person or entity who can halt the process or stop it from taking place; and finally the environment $(\mathrm{E})$ which represents the constraints under which the process takes place. The SIPOC model is an extension of the standard input-process-output (I, P, O) systems paradigm to include the 
supplier $(\mathrm{S})$ who is the provider of the inputs, and the customer $(\mathrm{C})$ who is the receiver of the outputs of the process.

The SIPOC and CATWOE tools are complementary. The SIPOC tool focuses more on the process flow itself and identifies and specifies the various elements within the process flow. The CATWOE tool takes more into account the context under which the process takes place. It considers the philosophy underpinning the process, the environmental constraints and the critical stakeholders in the process: customer, actors, and owners. The CATWOE approach also emphasizes the importance of understanding the nature of the transformation that takes place: what is transformed and how is it transformed. Whereas SIPOC emphasizes supplier and customer, CATWOE makes explicit the actors involved in carrying out the transformation process and the customer as beneficiary of that transformation. While each tool separately provides a considerable amount of information, used together they provide a more holistic view of a process and also act as a cross check on each other.

\section{UNIVERSITY TEACHING AND LEARNING PROCESSES}

The author, drawing on a decade of professional experience as a business analyst and fifteen years as an academic with experience of teaching in the European and US systems, has identified six key processes that are carried out in fulfillment of the university teaching mission. These key processes are primarily based around the life cycle of knowledge: its aggregation firstly into programs and then more finely into courses, its transmission via class meetings, its internalization during study, and the verification of its transmission and internalization through assessment, grading and award. The paper does not attempt to carry out a full process analysis of the teaching and learning function of a university as this would involve examining the creation, maintenance and deletion processes for each entity relevant to a university including programs, courses and assignments and students, as well as 
consideration of a great number of additional processes such as student enrolment, student feedback, plagiarism handling, student review of teaching, quality assurance, course review and program review. Instead the paper concentrates on entity creation processes: those processes that create programs, courses, class meetings, assignments, grades and graduates. These entities are shown in figure 1 in the form of a simplified entity relationship diagram (Lejk \& Deeks, 2002:115). The crows foot symbol represents 'many' and the diagram can be read as follows: 'a program comprises many courses', 'a course is held as many class meetings', 'a course contains many assignments', 'a course has many students enrolled on it', 'an assignment leads to many pieces of student work', 'a piece of student work is submitted by a student enrolled on the course' and so on. The processes examined in the paper revolve around the use of these entities. For example, in the assessment process a student completes an assignment and submits it as a piece of work for grading. In the grading process the instructor takes a piece of submitted student work and grades it. Note that the paper does not examine the process of creating knowledge itself as this is primarily a research rather than a teaching and learning process. insert figure 1 around here

The six teaching and learning processes examined in this paper are: program development, course design, class meeting, study, assessment and grading. The program development process takes place when the need for a new program is identified. The course design process then turns domain knowledge into the formal materials of a specific course that students will undertake. During class meetings these materials are conveyed to the student through a variety of means: seminars, facilitated workshops, formal lectures, case discussions, business simulations, laboratories, tutorials and many more. In the study process the student takes these materials and through self or supported study consolidates his or her 
learning. The assessment process assigns work to students that they must complete and submit for grading; work may take place in a formal terminal examination setting or continuously during the course in the form of reports, essays, or other formats. The grading process then determines the extent to which the student has engaged with and assimilated the materials; typically the output of the grading process is a grade for each piece of work. These are the bread-and-butter processes of teaching and learning: the processes on which academics spend most of their teaching and learning time. It is clear that they are closely interlinked in a value chain (Sasse et al., 2008) with in many cases the output of one process becoming the input of another. However, although interlinked, the processes tend to be carried out in a very separate fashion within universities. The processes are summarized in table 1 and examined in detail in the following sections. insert table 1 around here

\subsection{Program development}

The program development process transforms a societal requirement for the transmission of specific knowledge into a defined program of study to be made available to students. It normally comprises a number of specific courses or themes each of which has its own content, topics, teaching methodology and assessment approach. Program development is a long and complex process and continues throughout the life of a program (Buckley \& Monks, 2008). The output is comprised of specifications for the entire program and detailed descriptors for each course within the program; second order outputs are course brochures, websites, advertisements, posters etc. The outputs are directed in the first instance at various committees and panels, for example accreditation and validation panels at school and university level that must assess and approve the new program. Outputs of a newly accredited program are directed at potential students who may wish to undertake the program and at professors who will use them to carry out detailed course design. Professors therefore are the 
customers for one output of the process: course specifications. Professors will use these as a starting point when designing their courses in detail. Potential students are also customers in that they are recipients of marketing outputs and use these materials to decide whether or not to sign up for a program. The actors are the program development team under the leadership of the program chair or director. The owner of the process is the school that initiated the program and that presumably has the power to retire the program; from a practical point of view the owner is usually the Head of School or Dean of Faculty.

Clearly this is an intricate and complex process that takes place over a long duration, often several years. The process occurs only rarely and is most probably initiated by the school itself whenever it determines a need for a new program. Society is the supplier of inputs in the form of specific requirements for the program. An environmental scanning process may take place before this in order to determine a need for a new program. The transformation that takes place is that a relatively abstract societal need for formalized knowledge is turned into a formal program with a defined set of modules and an outline specification for each of those modules. The world-view under which the program development process is carried out is that there exists an accepted societal need for specific knowledge transmission and that universities are appropriate providers of such transmission. External constraints on the process are that sufficient demand exists for the program, that sufficient resources are available to deliver the program, that the School is credibly capable of delivering the program, and that the program merits delivery at university level. Some form of accreditation sub-process will usually take place to ensure that the program will meet these constraints before it is launched. The SIPOC elements of the process are illustrated in figure 2 (indicating from left to right: supplier, inputs, process, outputs and customer) and CATWOE elements of the process are given in table 2 . 
insert figure 2 around here

insert table 2 around here

An implication of this analysis is that there are two customers - potential student and professor - and each has distinct needs. The potential student requires information about the program in order to make the decision whether or not to enroll on the program. The information must give the potential student a description of the program and the courses on the program, ideally in layman's language. Such information about the program is created primarily for the purpose of marketing the program. On the other hand, the professor requires information about the program in order to prepare the actual course to be delivered onto the program. This information has an operational purpose and must be sufficiently detailed so as to provide clear guidance to the professor about the requirements of the program. It is important that these distinct requirements of the two sets of customers are clearly understood, else the university runs the risk of providing the wrong kind of information about its programs; for example far too detailed information to potential students or information too scant to accurately guide professors.

\subsection{Course design}

Course design is a strategic educational process and is crucially important in achieving effective student learning (Schmidt-Wilk, 2011). Whetton (2007) suggests that good course design centers around three main outputs: learning objectives, learning activities and learning assessment. The formal output of the course design process comprises a set of materials that make up the course. The nature of these outputs is usually defined by the university and may include a detailed course outline, a list of recommended textbooks, and a list of required readings, slides and presentation materials, case studies, tutorial sessions, laboratory schedules, schedule of class meetings, schedule of assignments and so on. The inputs 
comprise domain knowledge in the form of concepts, topics, theories, frameworks, models, teaching approaches and conventions that comprise the body of knowledge in a particular discipline, field or research area. The inputs also comprise a course descriptor that specifies the nature and specific requirements of the course, set in the context of the program as a whole. Recall that the course descriptor is an output of the program development process. The course design process is illustrated graphically in figure 3 and the CATWOE elements of the process are given in table 3.

insert figure 3 around here insert table 3 around here

The transformation that takes place in the process is the distilling of the body of knowledge in the field into a format that can be delivered in appropriate chunks to a cohort of students following a specific program of study. The primary actor in the process is the professor who will carry out the transformation using the knowledge, skills and experience that they have gained over the course of their career. The person who will receive these materials is the student undertaking the course; by definition the student therefore is the customer. The main suppliers of inputs are the academics in the field who have created and codified the domain knowledge. The program chair who supplies the course descriptor, which acts as a broad template for the course, is also a supplier. The owner of the process is arguably the program chair or the department head, either of whom may remove a specific module from a program.

The world-view underpinning this process is that the individual professor is the best person to define the specific content for the course and then go on to develop the course. While there is some movement toward team development and teaching of courses, most courses are developed by a single academic and are the responsibility of that academic. This has the 
advantage that individual academics relate strongly to and identify with their courses leading to a greater engagement by the professor in preparation and delivery of the course. It has the disadvantage that courses may be somewhat idiosyncratic and two courses with the same title may turn out to have quite different content, delivery and assessment mechanisms. It also has the disadvantage that courses may be designed to suit the instructor rather than the student. For example, courses may be designed to further the research or practice interests of the professor. Indeed the choice of course itself may reflect the interests of faculty rather than what is best for the student ${ }^{\mathrm{i}}$.

An environmental constraint is that courses must fit within an academic time frame, usually a semester but sometimes an academic year. The course therefore must be of sufficient size to warrant a semester but not so large that it is impossible for students to absorb the material in the timeframe allowed. Another constraint is that a course must fit within the domain of experience of a single academic. However, this constraint may be lifted with a move towards team teaching of courses. There are a number of possibilities here: two or more academics could deliver the entire course, both academics being present at each class meeting, bringing a variety of viewpoints to bear on a topic and so providing a stimulating if costly learning environment. A second possibility is that academics could specialize at topic rather than course level, each academic taking a number of topics on a course. While this will increase the variety of inputs into a course and allow individual academics to focus on specific topics it will also dilute the role and responsibility of the individual academic with respect to the course as a whole. This approach will also switch the basic unit of academic workload from course to topic, the ramifications of which are not clear. 
An implication of this analysis is that students are the customers of the course design process and outputs should be tailored to their needs. For example, course materials should be clearly written, unambiguous and understandable to students; prescribed texts should be readily available and not overly-priced. Professors may need to check that texts are available in the university library and, if not, request that they be made available. Students should be made aware of any specific costs that they will be expected to bear e.g. for business simulations, site visits and so on. Students should be made aware of instructor expectations regarding their participation in and contribution to class meetings. Details of assessments and deadlines must be made clear to students from the outset and not drip-fed (unless that is intentional from a pedagogic point of view).

\subsection{Class meeting}

During the class meetings the set of raw materials that comprise the course are read, considered, discussed, analyzed, debated and evaluated by students and the instructor. Class meetings usually take place over relatively small periods of time (one to three hours) and are spread out over one or two semesters. The main customers are the students who receive the materials and are led through them by the instructor thereby gaining a greater appreciation of the materials. However, the instructor herself arguably is also a beneficiary of the process as typically her own understanding of the materials is augmented through meeting with the class. For example, while the instructor may present and explain the materials to the students, the students in turn may make comments, ask questions, and generally critique the materials. This questioning, commenting and critiquing can result in an improvement in the instructor's own understanding and appreciation of the materials. The instructor in her turn may further consider, review and evaluate the materials. 
The primary actors in the class meeting process are the instructor and the students. The instructor may be the professor who designed the course but could be a different professor, lecturer or teaching assistant who did not design the course but who is to deliver it. There are a number of reasons why the instructor may not be the same person as the professor who designed the course: the course may be delivered multiple times in a semester, for example to different cohorts of students or different programs of study, and this may necessitate multiple deliveries by several different people; or the course may have been designed a number of years prior to delivery by a professor who has since departed from the institution. The instructor is the main actor in that he or she is responsible for organizing and choreographing the meeting.

The world view underpinning the class meeting is that learning requires the student and the teacher to meet up in some forum and on a regular basis. A staged transmission of materials from instructor to student is required for learning and this transmission takes place through a series of meetings, either physical or virtual, between instructor and student. Note however that the class meeting process takes place irrespective of the learning paradigm employed: traditional lecture or co-creation of learning. Under both paradigms students and instructors meet up in the one location. However the roles of students within the meeting are very different under the two paradigms. The traditional approach is that class meetings take the form of lectures where the instructor delivers the material and students listen and take notes. This traditional approach places students in a passive role in class meetings, their interaction being limited to asking the occasional question. However the role of students in classrooms is changing: students are increasingly being viewed as co-creators of learning and are being actively encouraged by instructors to take on a more active role in the classroom. For example, in business school classroom students regularly make formal presentations, provide 
critiques of theory, analyze case studies, examine business scenarios and discuss management situations. Even when students adopt a passive role they are co-creators of knowledge in that they listen to the instructor, absorb the materials, make notes on or annotate the materials, each in their own way according to their abilities, aptitudes, prior knowledge and well-being on the day. Whether active or passive each student undergoes a unique learning experience during the class meeting itself.

This new role for students in turn alters the role of instructors. They must move from acting as traditional lecturer and fount of knowledge - the sage on the stage - to that of facilitator of student learning - the guide on the side. Instructors elicit opinions and ideas from their students and draw them more into the process of learning. In tandem with this change in style is a change in the power relationship between students and instructor. In lecturer style class meetings power and control resides almost entirely with the instructor. He or she decides the order of the topics, the points to be covered under each topic, and the time to be spent on each topic during the class. In facilitator mode class meetings the instructor is forced to move more according to the pace and interests of the students. A consequence of this is that more time than planned may be spent on a topic if that topic turns out to excite student interest. That in turn may mean that another topic may need to be covered more quickly than planned, or not at all. The instructor is no longer all powerful or all controlling: some power and control is ceded to students.

Other relevant actors are administrators who ensure the meeting is scheduled, that the room or theatre is prepared, and that the materials are all in place either physically or online. Guest speakers or other visitors, teaching assistants or demonstrators may also play a role. The main supplier of inputs into the process is the instructor although students also provide inputs in 
the form of presentations, additional materials, and their own ideas. The owner of the process is the instructor who can cancel or reschedule the meeting. The class meeting process is illustrated graphically in figure 4 and the CATWOE elements are summarized in table 4. insert figure 4 around here insert table 4 around here

There are significant environmental constraints at play. Students are less interested in coming into a physical college resulting in universities providing more flexible meeting modes such as block and intensive week-long deliveries in place of the traditional two one-hour weekly meetings. New information technologies increase the reach of professors allowing lectures to be delivered remotely via the internet, World Wide Web and teaching platforms such as Moodle and Blackboard. A plethora of new electronic teaching tools such as podcasts, videos, email, social media and electronic discussion forums have become available.

Environmental constraints are impinging on the class meeting process in another significant way in recent years. For several thousand years teaching and learning has taken place primarily in a classroom. Concepts are transmitted directly from instructor to student in the same physical space. The advent of online technology now offers the option of a virtual classroom: students no longer have to be present in the same physical space at the same time. Online offers two new distinct virtual spaces: synchronous and asynchronous. Class meetings can take place with all participants present at the same time and with direct connections between them, i.e. class meetings may take place in virtual space but are synchronous, for example webinars. Class meetings can also take place asynchronously where participants do not meet up in the physical world but also do not need to be present at the same time, i.e. meetings are asynchronous. Various transmission media such as websites, podcasts, email 
and so on fall into this category. Indeed courses of the future will likely use a variety of class meeting types, for example a combination or blend of physical class meetings together with virtual but synchronous meetings and supported by a variety of asynchronous mechanisms.

A third environmental change taking place is that, at senior university management levels, students are being viewed as customers who receive a service from the instructor. It is common practice for students to rate instructors using in-house end of semester surveys or independent websites. In-house surveys may be carried out by a quality control function within the university but independently of the instructor. Instructors need to be aware of this increasingly customer-centric view of student at higher levels of the organization, even if they themselves view students as having a multiplicity of roles.

There are a number of implications from this analysis. Firstly, there is no single clear-cut customer of the class meeting process. Students and instructors both are customers in that each receives benefit from the outputs of the process. Secondly, students and instructors play a multiplicity of roles in the process. While this makes the class meeting a more dynamic event it may be create confusion for students. They may be unsure as to how to prepare for the class meeting. They may be unsure as to what role they are expected to play during the meeting. They may be unsure as to when their role changes during the meeting. It is therefore essential that the instructor prepares students for the meeting and keeps them informed during the meeting as to what their roles are at any point in time. Students may not all play the same role at the same time. For example, one set of students may be presenters while another set may be peer assessors. These various roles must be clearly pointed out to students. All this choreography takes time and the instructor must allow time for this before and during class meetings. 
Thirdly, as the number of student roles increases control over the process by the instructor reduces. This can empower students and increase the level of their engagement in the meeting thereby enhancing their learning experience. However it may also mean that material that the instructor intended to cover in the meeting ends up being left out. Students may react against this: they may feel deprived of that material or they may feel irritated at having to spend time reading up on material not covered in class. Clearly a great deal of judgment must be exercised by the instructor as to what to cover and when to let a discussion continue, all the while under the spotlight. Instructors may ease their predicament by pointing out to students the nature of the class meeting process, the multiple roles being played by the students, the instructor's expectation of each role, and the multiple roles being played by the instructor. The instructor may seek help from the student's in carrying out his or her role e.g. by asking students to act as time keepers or as peer assessors. This of course creates even further roles for students.

Fourthly, students and instructors play several roles simultaneously. This is a very difficult thing to do for both parties but particularly for the instructor. The instructor must retain in his or her head the order of events to take place during the meeting, must issue notes or handouts to students, must formally present materials to students verbally and possibly with an accompanying slideshow, must elicit comments and contributions from the audience, must field questions from students, and may have to assess performances and determine grades for individual or group contributions to the meeting.

Fifthly, instructors may need to consider locating class meeting in venues other than physical classrooms. Online classrooms offer a number of significant advantages (and also some 
disadvantages) over traditional physical spaces. However instructors may need to increase their online teaching and learning knowledge and skills in order to consider and take up these new online opportunities. Another consideration is that students may be more familiar than instructors with these new technologies further eroding the power gap between instructor and student and possibly resulting in some further discomfort on the part of instructors.

\subsection{Study}

The study process is largely carried out by the student with relatively little involvement by the university. The student supplies most of the inputs: an appreciation of the course materials gained from lectures and from prior study and the course materials themselves annotated by the student. The transformation that takes place is the consolidation of these inputs in the mind of the student through reading, practice, solving problems, writing out summaries, making further notes and so on. The student himself also becomes gradually transformed as the process is carried out over the duration of the course. The professor may provide some input such as guidelines for study in the particular subject area but the student is the main actor in the process as it is he or she who does the work of studying. The student is also the customer in that he is the beneficiary of the process: he gains the learning or struggles with the material. The output is some form of consolidated understanding of the topics and concepts presented during the course. The student is clearly the owner of the process: the student can stop and start the process at will.

Unlike at second level the university tends to involve itself very little in the study process other than in the provision of study space and study materials, usually within the library. The worldview here is that students should largely be capable of studying by themselves, with relatively little formal direction or support being required. However, professors may become involved in the process if students contact them with queries about concepts, topics or 
materials. The extent of such contact is variable and depends on the nature of the materials, the confidence and maturity of the student, access to the university and availability and approachability of professors. Contact is usually initiated by the student.

A number of environmental constraints exist. Places in libraries may be insufficient at peak periods forcing students to study in less desirable locations for example school corridors, empty classrooms or coffee shops. Environmental factors such as small tables, background noise, glaring lights and interruptions militate against successful study. Lack of parental and peer support may de-motivate students. Social or other activities divert students from study. The study process is illustrated in figure 5 and the CATWOE elements are summarized in table 5 .

Study is often the Cinderella of the teaching and learning processes: it gets least attention from faculty and relatively little in the way of resources from the university. However an implication of this analysis is that study is recognized as one of the six teaching and learning processes. This may raise its profile and encourage universities to take the study process more seriously. While some initiatives could be undertaken by individual professors such as provision of worked-examples, full-scale support for student study probably requires a response at institutional or school level. Such support could be aimed at reducing the impact of environmental constraints on student study, for example setting up study advice centers or drop in clinics, by providing training in study skills or by fostering the creation of study groups among students. Indeed a university could increase its level of support for study to such an extent that it becomes a differentiating feature of the student experience, one that may distinguish the university from its competitors. 


\subsection{Assessment}

This process allows students demonstrate their knowledge of the materials that have been presented to them during the course. It usually takes two forms: a formal examination at the end of the semester or continuous assessment work that is carried out during the semester. During the process the examination questions are transformed into answers written onto the exam script. By means of continuous assessment, assignment requirements are transformed into a finished piece of work such as an essay, oral presentation, and project or laboratory reports. The actor carrying out the process is the student who either sits the examination or submits the assignment. The input to the process is the specification for the assessment: an exam paper in the case of terminal examination and assignment requirements in the case of a piece of continuous assessment. The supplier of these inputs is the professor. The output of the process is the student's work. This may be in the form of an examination script or a piece of continuous assessment work such as a project, essay, report or presentation. The customer of the process is the professor who receives the scripts or student work and who will later go on to examine and grade these materials.

Arguably the owner of the process is the university as a whole: it would require a very senior authority to stop an examination process as examination and assessment are fundamental and crucial activities of a university. This is a rare occurrence but does occasionally happen: for example, exams may be postponed due to severe weather, outbreak of disease or due to some other kind of emergency situation. It could also be argued that the owner of the process is the individual student who may choose not to complete an assignment or not to sit an examination; in this case it is not the entire process that stops, merely an instance of the 
process. The assessment process is illustrated graphically in figure 6 and its CATWOE elements are summarized in table 6.

insert figure 6 around here

insert table 6 around here

A suggested world view under which the assessment process operates is that students must be forced or coerced into learning by having to complete some piece of work that they must hand up for formal examination, and that the work must clearly have been carried out by themselves alone and unaided. The world view under which continuous assessment operates is that students will learn by doing and must be motivated to learn not only at the end of the semester but also during the semester.

An environmental constraint impinging on this process is the trend towards group work for continuous assessment. This provides an additional learning element for students but the process becomes less transparent making it more difficult for the examiner to determine the contribution of each individual student within the group. It may also lead to inter-group conflict and social loafing (Bailey et al, 2005). Assessment trends are often determined by societal needs. For example, in business schools continuous assessment is often carried out through teamwork in order to prepare students to work in industry. An emphasis on oral assessment reflects industry's desire for graduates who are capable of making business presentations ${ }^{\text {ii }}$.

An implication of this analysis is the recognition that assessment is a process in its own right and not merely a bit player in the class meeting or course design process. Arguably in the future world of online teaching assessment will take on a greater importance, particularly at 
local level. While it is feasible that transmission of knowledge through class meetings could become more and more centralized, with a smaller number of well-resourced world class institutions providing the bulk of knowledge transmission, assessment will always be carried out at local level because of the large amount of work involved. Smaller or local universities may come to depend more and more on the assessment and grading processes for their livelihood.

\subsection{Grading}

The inputs to the grading process are the students' work in the form of examination scripts and submitted assignments. This work is then examined by the instructor and the output is a grade for each piece of work. The overall output is an aggregated grade for each student on a course. Grading is carried out by the professor or other member of the academic staff. The grading process is illustrated graphically in figure 7 and the CATWOE elements are summarized in table 7.

A number of different worldviews underpin this process. Firstly is the view that universities assess students on their academic abilities and not on other abilities: social, interpersonal, cultural, sporting, entrepreneurial and so on. This view has changed somewhat in recent years with some universities now also taking in account extra-curricular activities. Secondly is the view that the grade is a reasonable representation of the academic ability of the student. Thirdly is the view that the submission of materials for grading requires the use of the written word (incorporating letters, symbols or numbers) either in the form of questions or in the form of answers. Even use of multiple choice questions assumes a strong ability to understand the written word; mathematically based questions require the ability to understand written symbols and written words. 
Several environmental factors constrain this process. Firstly, not all students are equally adept at relating to the written word. Increasingly this is taken into account in examination and in assessment; for example students with special needs may be examined under different conditions and assessed under special guidelines. Secondly, the increasing use of group work makes it difficult to assess the contribution of an individual to the work of the group. Assigning a group mark to each individual within the group may not correctly assess individual contributions to the piece of work under consideration. Thirdly, there is increasing use of alternative media to the written word, for example: verbal presentations, prototypes, computer applications. These alternative modes of submission may require alternative means of assessment and recording and archiving of submissions. insert figure 7 around here insert table 7 around here

The grading process is one not traditionally favored by academics with many finding it tedious to carry out. Grading of examination scripts is not an easy task and requires experience, knowledge and discipline especially when large numbers of students are involved. Grading of other written materials such as individual essays or group case analyses also require similar attributes on the part of the grader. Maintaining standards across a large class of students or across multiple graders requires a considerable amount of discipline and coordination. However, the comment made under assessment may also apply to the grading process: should the academic world become more centralized and globalized, grading will likely be carried out locally due to the volume of work involved. In such a future grading and assessment could become the bread-and-butter activity of local academic institutions with knowledge transmission becoming the preserve of well-resourced world class and worldscale institutions. 
The exception to this is the grading of multiple choice tests: these could be carried out remotely and on a large scale through the use of web-based automated tools. Such a form of assessment and grading could be carried out on a global scale. Indeed SATS and GMAT tests have been carried out on a global scale for many years, even before the advent of modern web-enabled information and communications technologies. It is therefore feasible for a large global academic institution to set up global scale courses with global scale virtual class meeting, assessment and grading processes, supplemented if necessary by a local physical tutorial style class meeting process. This argument suggests the possible advent of global clusters of business schools centered on a world class institution that designs the course and conducts the main class meetings using faculty with worldwide reputations and supported by country-based business schools that carry out assessment and grading processes together with

some local class meetings. A second possible future is for strong country-based business schools to carry out course design, selecting best virtual elements from institutions around the world and coupling this with some local class meetings using school faculty.

\section{DISCUSSION AND CONCLUSION}

This paper examined in detail six university teaching and learning processes using a combination of two techniques from the fields of operations management and systems analysis: SIPOC and CATWOE. The paper determined that instructors and students play multiple roles in these processes with students taking roles of actors, customers, suppliers, raw material and end product and with instructors taking roles of owner, actor, supplier and customer. With respect to certain processes, the paper suggests that instructors and students take on multiple roles simultaneously. This is particularly so in class meetings illustrating the complexity inherent in that process. The paper argues that it is useful for instructors to appreciate these different roles that both they and students bear. The paper also argues that 
universities must strive to make students aware that they too have multiple roles to play in the process of their own education.

The main conclusion to be drawn from the analysis is that to view students uniquely as customers is somewhat simplistic. While students in some respects are customers, for example in the course design and class meeting processes, they also play many other roles in the work of the university. They are actors in the assessment process. They are owners of the study process. Students may even have multiple roles in a single process. For example, as well as the role of customer they may also play the roles of actor in the class meeting process, and may also be a supplier of inputs into that process. Furthermore, students may find themselves in a number of roles in different processes at the same time: for example, during a typical week students will attend lectures, complete assignments, and receive feedback on already submitted work. During a single class meeting students may receive materials and information as customers, may supply inputs such as a presentation on a case study, and may actively participate as actors in creating knowledge through their observations, comments, questions and answers.

The second conclusion to draw from the analysis is that with respect to some processes students are customers. This recognition puts an onus on the university to meet students' needs with respect to these processes. For example, course materials, which are the outputs of the course design process, should be made available to students on time and in a format that is clear and easily understood. Universities must ensure that the program development process provides potential students with timely, meaningful and correct information about courses and university procedures. In the class meeting process materials such as slides and handouts must be made available to students in a timely fashion and the materials themselves 
should be appropriate, readable and properly presented. However, it is also clear that there exist other customers for teaching and learning processes: the instructor is also a customer, for example in the program development, assessment and class meeting processes. Students must be encouraged to meet the needs of their customers by providing properly completed assignments and by being fully prepared for class meetings.

We should also be mindful that Checkland's view of customers is that they are beneficiaries of the outputs of the process. Although students receive the output of the grading process, and in that sense are customers, there is no implication that as customers they should be happy or satisfied with that outcome i.e. with the grade itself. It is however reasonable for students to expect to be satisfied with the conduct of the process: that the grade is a fair reflection on the work carried out, was determined in an impartial manner and was received in a timely fashion. Similarly, in class meetings students may find course materials tough-going, challenging and overwhelming at times. Such confusion may lead to a perception among students that their needs are not being met in turn leading to a feeling of customer dissatisfaction. What is important is for students to realize, or be brought by instructors to realize, that they play multiple roles in class meetings, and that responsibilities attach to those roles. Students in class meetings are not merely passive receivers of information but active participants. Students should be satisfied with the conduct of class meetings; whether or not they are satisfied with outcomes also depends on the effort they put in themselves.

This view makes class meetings entirely different to attending the theatre or cinema where the customer takes an almost entirely passive role and is there solely to be entertained. Empirical work has shown that students identify themselves with a single role and that this role conditions their perception of their educational experience (Halbesleben \& Wheeler, 
2009). This paper suggests that educators must bring students to the point where they recognize that they play multiple roles in education processes. These roles are not simply metaphors describing how students view learning (Bozlk, 2002) but real roles with real responsibilities. Instructors must take into account the role that students are playing in order to set up conditions to stimulate student engagement in their learning (Halbesleben \& Wheeler, 2009).

A third conclusion is that professors also play multiple roles in teaching and learning processes; indeed like students they may carry out multiple roles within the one process and they may play several of these roles simultaneously. For example, professors are actors in course design, owners of class meetings, and customers for assessments. It is vital therefore for professors to be aware of the role, or roles, that they are playing at any particular time. This is not an easy thing to do as the instructor is usually the one in the limelight and often has little support. This is particularly so in class meetings where the instructor must simultaneously provide their own inputs, elicit student inputs, deal with impromptu events such as questions, comments and interjections, deal with noises, backchat and other distractions, evaluate student inputs, and as lead actor choreograph the entire session. In a single classroom session the instructor therefore may act as actor, supplier, customer and owner. It may even be worthwhile creating separate real or virtual sections within a classroom session to separate out these roles. An instructor could take up a different physical position within the classroom to signify a change in role. For example, the instructor goes to the front of the class when delivering inputs but moves to the back of the class when evaluating formal student inputs such as presentations. Preparation of students for roles is also important. Habesleben \& Wheeler (2009) suggest that instructors formally discuss with students the roles that they are expected to play, and actively prepare students for these roles. 
A contribution of this paper is to note that students may need to be prepared to take on multiple roles simultaneously.

A fourth conclusion is that the set of teaching and learning processes are highly integrated and inter-related. The output of one process is often the input to a following process. This implies that changing a process may have an effect on other processes, both upstream and downstream. For example changing mode of delivery or class meeting format may require a change in mode of assessment. The reverse may also be the case: changing assessment mode may require a change in the class meeting process. For example, the current trend towards increased use of group work on the one hand and a requirement to develop students' presentation skills on the other hand requires changes in a number of processes. In the course design process this new work must be designed into class meetings and into the mode of assessment. For example, class size may need to be reduced and the protocol within class meetings may need to change to accommodate group presentations. The meeting room itself may need to change, e.g. to a bigger or smaller room, or from flat to tiered. The assessment process may change because groups, not individuals, are now being assessed (but grades may still apply to individuals) and presentation skills may need to be assessed by means other than the traditional written word. The main actor in these different processes may be different and it can easily happen that communication between these different actors breaks down. Instructors embarking on new teaching initiatives may find themselves overwhelmed by existing procedures and bureaucratic structures within universities - to the point where innovation becomes stifled and naturally innovative instructors start to curb their own enthusiasm. Universities must work to ensure that bureaucracy does not get in the way of innovation, that lines of communication are fully open, that innovation in one process is properly, but also easily, reflected upstream and downstream. This paper suggests that 
understanding the six main processes underpinning education transmission and identifying the actors involved and the roles they play will aid universities in streamlining the linkages between processes.

A fifth conclusion is that all processes are not viewed by universities as being of equal importance. For example the study process is largely hidden from faculty and universities typically devote relatively little resources to it. A university that places emphasis on supporting the study process may be able to create a competitive advantage for itself; for example, study support could be provided by ensuring that examination requirements are clear to students, by increasing access to the library, by providing tutor support or by ensuring that course materials are readily available online. On the other hand universities typically devote a great deal of time, energy and resources to class meetings. Grading is a process that professors tend to carry it out where and whenever they can fit it in. Course design may be carried out by senior staff with lecture delivery carried out by junior or adjunct staff leading to inconsistencies or gaps between what was intended and what was actually delivered. Such asymmetric allocation of resources implies that universities view these processes to be of differing importance. An awareness of the fact that there are at least six distinct processes may help make faculty more aware of the separate importance of each process and the importance of consistent interlinking between one process and another.

A sixth conclusion is that universities of the future may choose to focus only on certain processes instead of attempting to carry out all six as is currently the case. For example, wellendowed universities with global reputations could choose to concentrate on program development and course design processes and license out delivery processes to local institutions. In such a disaggregation of the educational value chain (Sasse et al, 2008) these 
global institutions will focus on upstream elements. Local level institutions could choose to focus on the processes that are student intensive - study, assessment, grading and graduation: i.e. on downstream elements of Sasse et al's (2008) educational value chain. Until the advent of a reliable delivery technology that can function at global scale the class meeting process will probably remain at local level. However collaboration between local and global universities could lead to a blended set of class meetings, with physical meetings taking place at local institutions and some of the virtual meetings taking place at global level in conjunction with the global partner.

A final point to be made is that arguably the above processes are all sub-processes within a super-process: that of enriching or driving forward society. Here the transformation that takes place is on society itself whereby as a result of the entire set of activities carried out by the university society is enriched and developed. The inputs are the young students who come in as freshmen. Graduates, capable educated citizens, are the output and the customer is society itself. The suppliers are parents or industry who put forward their children or employees respectively for further education. The actors who carry out the transformation are faculty, administrators and the students themselves. Arguably the owner is also society, through government in the case of public universities and through funders or benefactors in the case of private ones, as it is society that either wishes to continue in the long run with the institutions we call universities, or not.

There are a number of limitations to this research project. The analysis is limited to six teaching and learning processes. However many more processes exist in a university and many of these are linked with teaching and learning. The research process which transforms data about the real world into codified knowledge underpins many of the teaching and 
learning processes, in particular program development, course design and class meetings. Similarly the administrative processes of fundraising, fee collection, recruitment, procurement and facilities provision provide the financing, faculty, equipment and facilities and other resources with which to carry out the teaching and learning processes. Other support processes also underpin the six teaching processes; for example, the workload allocation processes assigns instructors to courses and the quality assurance process assesses the quality of teaching; in many European universities there exists a sub-process within the assessment process whereby exam papers are sent to external examiners for approval before the examination is held. These research, administrative and support processes provide a fruitful avenue for future research into university processes. A further limitation of this research is that it is based on the author's experience and observations within a small number of universities; an avenue for future research is to determine the extent to which these six processes exist in other universities.

\section{Bibliography}

Acevedo, A. 2011. Business ethics 101: the student is not a customer. International Journal of Management Education, 9(3):1-11.

Antunes, D. \& Thomas, H. 2007. The competitive (dis)advantages of European business schools. Long Range Planning, 40:382-404.

Armstrong, M. 2003. Students as clients: a professional services model for business education. Academy of Management Learning and Education, 2: 371-374. 
Bailey, J.J. 2000. Students as clients in a professional/client relationship.

Journal of Management Education, 24:353-365.

Bailey, J., Sass M., Swiercz, P.M., Seal C. \& Kayes, D.C.. 2005. Teaching with and through Teams: Student-Written, Instructor-Facilitated Case Writing and the Signatory Code. Journal of Management Education, 29:39-59.

Bedeian, A.G. 2004. Peer review and the social construction of knowledge in the management discipline. Academy of Management Learning and Education, 3:198-216.

Bergrren, C. \& Söderlund, J. 2011. Management education for practicing managers: combining academic rigor with personal change and organizational action. Journal of Management Education, 35:377-405.

Bhote, K. 1992. The "next operation" is your customer. Supervisory Management, 39(1):8.

Bozlk, M. 2002. The college student as learner: insight gained through metaphor analysis. College Student Journal, 36(1):142-151.

Bridges, E. 1999. Experiential learning and customer needs in the undergraduate marketing research course. Journal of Marketing Education, 21(1):51-59.

Brysland, A. \& Curry, A. 2001. Service improvements in public services using SERVQUAL. Managing Service Quality, 11(6):389-401. 
Buckley, F. \& Monks, K. 2008. Responding to managers' learning needs in an edge-of-chaos environment: insights from Ireland. Journal of Management Education, 32: 146-163.

Checkland, P. 1985a. Achieving "desirable and feasible" change: an application of soft systems methodology. Journal of the Operational Research Society, 36:821-831.

Checkland, P. 1985b. From optimizing to learning: a development of systems thinking for the 1990s. Journal of the Operational Research Society, 36:757-767.

Crosby, P. 1979. Quality is free, New York: McGraw Hill.

Ferris, W.P. 2002. Students as junior partners, professors as senior partners, the B-school as the firm: a new model for collegiate business education. Academy of Management Learning and Education, 1:185-193.

Ferris, W.P. 2003. Why the partnership model's usefulness far exceeds that of the client model: reply to Armstrong. Academy of Management Learning and Education, 2:375-377.

Flannery, B.L. \& Pragman, C.H. 2010. Service-learning and integrated course redesign: principles of management and the campus kitchen metaproject. Journal of Management Education, 34:11-38.

Franz, R.S. 1998. Whatever you do, don't treat your students like customers! Journal of Management Education, 22:63-69. 
Gallos, J.V. 2008. Charting a new course for the scholarship of management teaching and learning. Journal of Management Education, 32:535-540.

Gillespie, T.L. \& Parry, R.O. 2009. Students as employees: applying performance management principles in the management classroom. Journal of Management Education, $33: 553-576$.

Gross, M.A. \& Hogler, R. 2005. What the shadow knows: exploring the hidden dimensions of the consumer metaphor in management education. Journal of Management Education, 29:3-16.

Halbesleben, J.R.B. \& Wheeler, A.R. 2009. Student identification with business education models: measurement and relationship to educational outcomes. Journal of Management Education, 33:166-195.

Hammer, M. 1990. Reengineering work: don't automate, obliterate. Harvard Business Review, (4):104-112.

Imai, M. 1986. Kaizen: the key to Japan's competitive success, New York: Random House.

Lejk, M. \& Deeks, D. 2002. An introduction to systems analysis techniques. Harlow, England: Addison-Wesley ( $2^{\text {nd }}$ edition).

McCollough, M.A. \& Gremler, D.D. 1999. Guaranteeing student satisfaction: an exercise in treating students as customers. Journal of Marketing Education 21(2):118-130. 
Mintzberg, H. \& Gosling,J. 2011. Educating managers beyond borders. Academy of Management Learning and Education 1:64-76.

Nelson, R. \& Winter S. 1982. An evolutionary theory of economic change. Cambridge, Mass.: Belknap Press.

Obermiller, C. \& Atwood, A. 2011. In defence of the student as customer metaphor. International Journal of Management Education, 9(3):13-16.

Pfeffer, J. \& Fong, C.T. 2002. The end of business schools? Less success than meets the eye. Academy of Management Learning and Education, 1:78-95.

Porter, M. 1985. Competitive advantage. New York: The Free Press.

Porter, T. \& Córdoba, J. 2009. Three views of systems theories and their implications for sustainability education, Journal of Management Education, 33: 323-347.

Pyzdek, T. 2003. The six sigma handbook. New York: McGraw-Hill.

Sasse, C., Schwering, R., \& Dochterman, S. 2008. Rethinking faculty role in a knowledge age, Academy of Educational Leadership Journal, 12(2):35-48.

Schmidt-Wilk, J. 2011. Course design as a strategic process. Journal of Management Education, 35:319-323. 
Shostack, G.L. 1982. How to design a service, European Journal of Marketing, 16(1):49-63.

Stepanovich, P. 2009. The lobster tale: an exercise in critical thinking. Journal of Management Education, 33:725-746.

Walker, K. \& Ainsworth, P. 2001. Developing a process approach in the business core curriculum. Issues in Accounting Education, 16:41-66.

Wallace, J.B. 1999. The case for student as customer. Quality Progress, 32(2):47-51.

Weller, L.D. 1998. Unlocking the culture for quality schools: reengineering. International Journal of Educational Management, 12:250-259.

Whetton, D. 2007. Principles of effective course design: what I wish I had known about learning-centered teaching 30 years ago. Journal of Management Education, 31:339-357.

Womack, J.P., Jones, D.T. \& Roos, D. 1991. The machine that changed the world, New York: HarperPerennial 


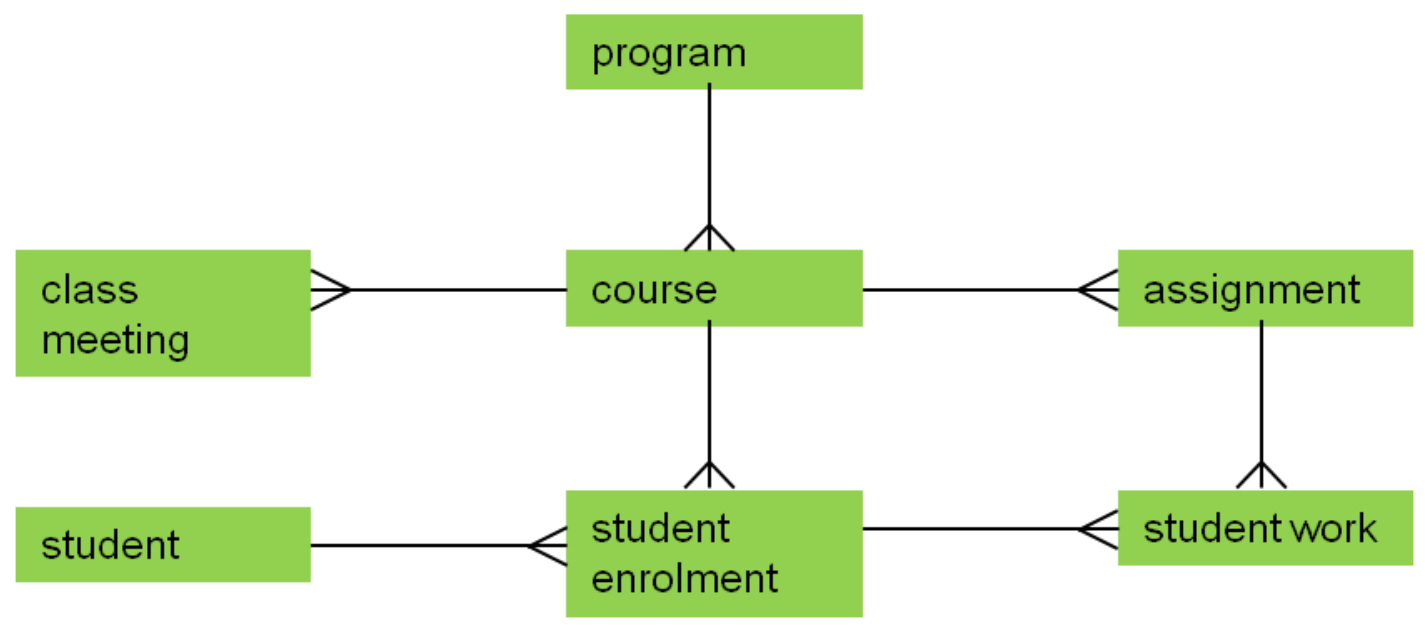

Figure 1: Model of entities relevant to teaching and learning processes 


\begin{tabular}{l|l|l|l|l} 
Supplier & Input & PROCESS & Output & Customer \\
\hline Society & Societal need & Program & 1)Program & Potential student \\
& & development & specification & Professor \\
\hline Program Chair/ & Course & Course design & Course materials & Student \\
Director & descriptor & & descriptors & \\
\hline Instructor & Course materials & Class meeting & Materials & Student \\
(and student) & & & appreciated & (and instructor) \\
\hline Student & Appreciated & Study & Concepts & Student \\
\hline Student & Student work & Grading & Grade & Student \\
\hline & materials & & internalized & \\
\hline
\end{tabular}

Table 1: University teaching and learning processes (SIPOC elements) 


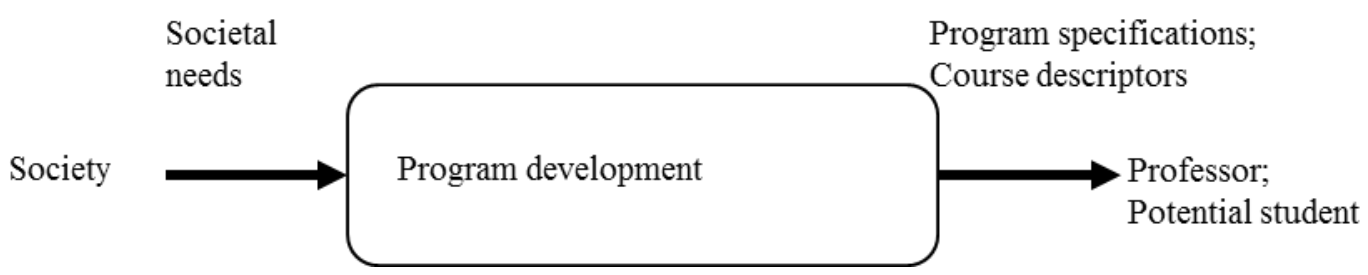

Figure 2: Program development process (SIPOC elements)

\begin{tabular}{|c|c|}
\hline & PROGRAM DEVELOPMENT PROCESS \\
\hline Customer & Professor; potential student \\
\hline Actor & Program Chair/Director; program development team \\
\hline Transformation & $\begin{array}{l}\text { To convert a societal need into an academic program of } \\
\text { study }\end{array}$ \\
\hline Worldview & $\begin{array}{l}\text { Society requires specific knowledge and the university is a } \\
\text { provider of such knowledge }\end{array}$ \\
\hline Owner & Dean of Faculty/ Head of School \\
\hline $\begin{array}{l}\text { Environmental } \\
\text { constraints }\end{array}$ & $\begin{array}{l}\text { Sufficient demand exists for the program; sufficient } \\
\text { resources exist to deliver the program; the university is } \\
\text { credibly capable of delivering the program; the program } \\
\text { merits delivery at university level; accreditation }\end{array}$ \\
\hline
\end{tabular}

Table 2: Program development process (CATWOE elements) 


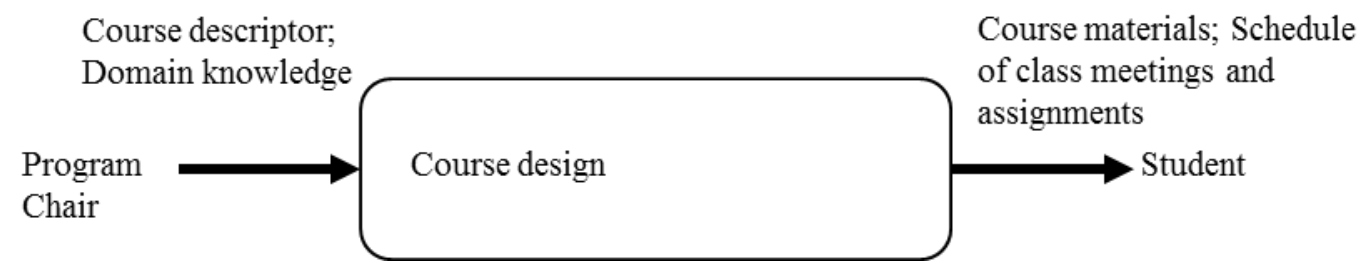

Figure 3: Course design process (SIPOC elements)

\begin{tabular}{l|l} 
& COURSE DESIGN PROCESS \\
\hline Customer & Student \\
\hline Actor & Professor \\
\hline Transformation & $\begin{array}{l}\text { To distil a body of knowledge into a format deliverable to } \\
\text { students } \\
\text { The individual professor is expert in the field and best } \\
\text { placed to design a program of study }\end{array}$ \\
\hline Worldview & $\begin{array}{l}\text { Program Chair } \\
\text { Course requirements are within a single professor's area of } \\
\text { Environmental }\end{array}$ \\
constraints & $\begin{array}{l}\text { expertise; Course is sized to fit within academic timeframe - } \\
\text { semester or year }\end{array}$
\end{tabular}

Table 3: Course design process (CATWOE elements) 


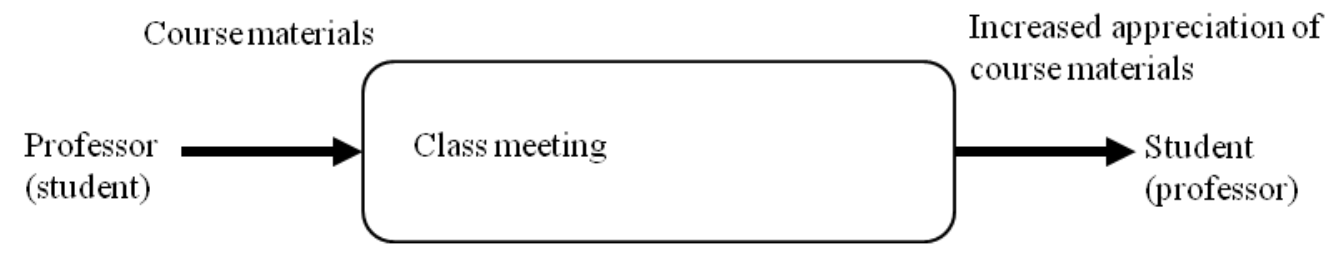

Figure 4: Class meeting process (SIPOC elements)

\begin{tabular}{|c|c|}
\hline & CLASS MEETING PROCESS \\
\hline Customer & Student \\
\hline Actor & Instructor; student; administrator \\
\hline Transformation & $\begin{array}{l}\text { Raw learning materials are transformed into appreciated } \\
\text { learning materials via the classroom process }\end{array}$ \\
\hline Worldview & $\begin{array}{l}\text { That a staged transmission of materials from instructor to } \\
\text { student is required for learning and that this transmission } \\
\text { takes place through a series of meetings, either physical or } \\
\text { virtual, between instructor and student }\end{array}$ \\
\hline Owner & Instructor \\
\hline $\begin{array}{l}\text { Environmental } \\
\text { constraints }\end{array}$ & $\begin{array}{l}\text { That the meeting room, whether physical or virtual, is } \\
\text { conducive to learning; that both instructor and student adapt } \\
\text { to the new roles of facilitator and co-creator of learning } \\
\text { respectively; Senior management's view of student as } \\
\text { customer; rating of instructor by students; technology }\end{array}$ \\
\hline
\end{tabular}

Table 4: Class meeting process (CATWOE elements) 


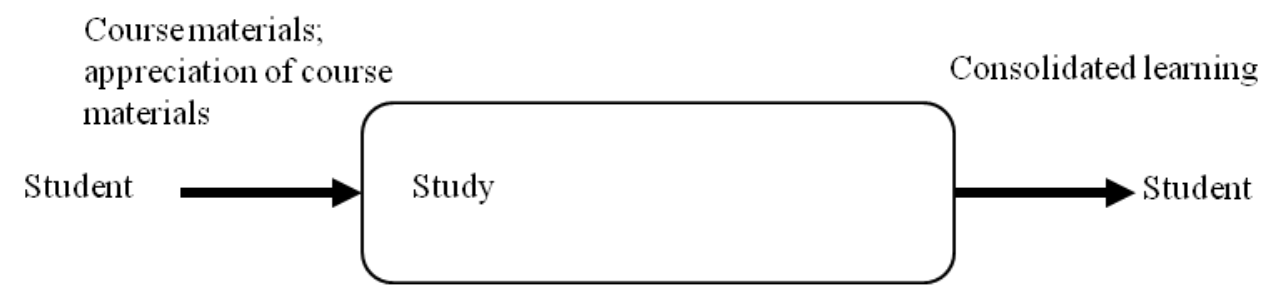

Figure 5. Study process (SIPOC elements)

\begin{tabular}{l|l}
\hline Customer & STUDY PROCESS \\
\hline Actor & Student \\
\hline Transformation & Learning materials are transformed into consolidated \\
learning & That students are largely capable of studying alone and \\
\hline Worldview & unaided \\
\hline Owner & Student \\
Environmental & Parental and peer support; availability and approachability \\
constraints & of professors; library study places
\end{tabular}

Table 5: Study process (CATWOE elements) 


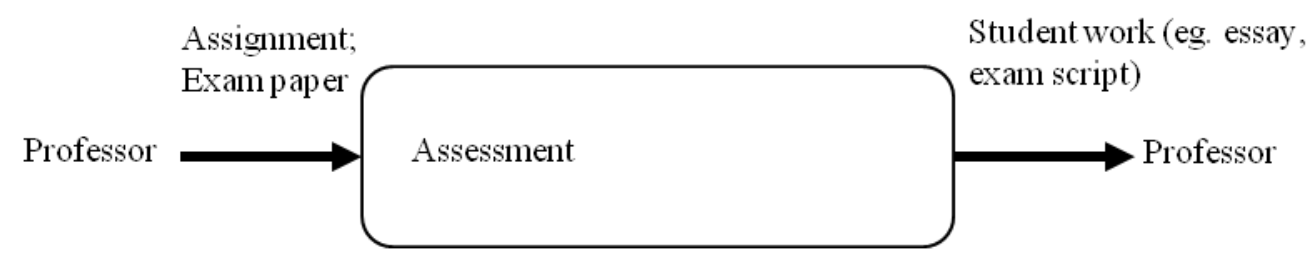

Figure 6. Assessment process (SIPOC elements)

\begin{tabular}{l|l}
\hline Customer & ASSESSMENT PROCESS \\
\hline Actor & Professor \\
\hline Transformation & An original piece of student work is created based on \\
requirements given in an assignment or exam paper \\
\hline Worldview & \begin{tabular}{l} 
That students must demonstrate their understanding of the \\
materials through individual terminal examination or \\
through continuous assessment \\
\hline Owner
\end{tabular} \\
\hline Environmental & School or university \\
constraints & social loafing.
\end{tabular}

Table 6: Assessment process (CATWOE elements) 


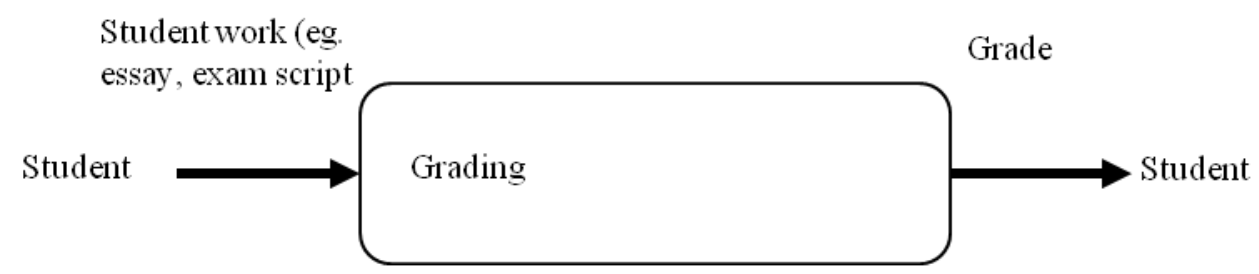

Figure 7. The grading process (SIPOC elements)

\begin{tabular}{ll}
\hline Customer & GRADING PROCESS \\
\hline Actor & Professor \\
\hline Transformation & Examination scripts and assignment materials are assessed \\
and a grade determined \\
That professors are best able to assess the level of learning \\
of students; that learning is best demonstrated through \\
written work; that learning is best demonstrated through \\
academic work \\
School \\
\hline Owner
\end{tabular}

Table 7: Grading process (CATWOE elements) 


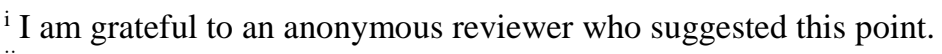
ii Ditto 